\title{
MYTHOLOGICAL, RELIGIOUS AND PHILOSOPHICAL WORLDVIEW DOMINANTS IN NOTARY ACTIVITY
}

\author{
Nataliia Manoylo \\ Private Notary, Kyiv City Notarial District, Candidate of Philosophical Sciences, \\ Doctoral Student, National Pedagogical Dragomanov University, Ukraine \\ e-mail: notarmanoylo@gmail.com,orcid.org/0000-0002-6369-7437
}

\section{Summary}

The notary system occupies a prominent place in any democratic and legal society. Proper performance of functions largely depends on the high level of professional qualification of notaries. The latter is achieved by what values dominate in their operational consciousness. With this in mind, the article considers the main types of worldview in their value manifestations in the process of communication of the notary with visitors and clients.

Since the worldview function is one of the central for philosophy, the principal value in all types of worldview, which include mythological, religious and philosophical, is man as a subject of knowledge. But only philosophy, advocating for self-knowledge, recognizes it as the highest value. In the mythological worldview, a man, when placing his mental inclinations in the natural environment, does not yet rise to the realization of his value and self-worth. Religious worldview, denying the anthropomorphic view of the world, is based on reason and will as world-creative principles. In fact, these are attributive value properties of man, which, because the interaction between people does not give grounds to claim that it is based on rational-volitional motivation, are alienated from real people in favor of the Absolute, which is God as the highest value, who through people like him in reasonable will and love, gives them instructions for life, which they, in fulfilling his will, convey to the average "sinful" people. The philosophical worldview is based on the fact that each person is able to assert their own self-worth if they engage in self-awareness through the opportunity to have freedom of thought, her and his spiritual-cognitive space created by prominent thinkers throughout the history of knowledge.

Knowing the peculiarities of a man's worldview motivation, the notary largely takes this into account when performing his professional duties.

Keywords: Worldview, man, notary, value, mythology, religion, philosophy.

DOI: https://doi.org/10.23856/4907

\section{Introduction}

Problem statement. In cognitive theory, the problem is defined as knowledge of ignorance. The education system provides general knowledge as objectively necessary, manifested in the law. Meanwhile, the worldview is defined as a form of individual selfawareness that motivates the way of life. The ability to act according to knowledge is limited by the fact that the habit of living as it was before receiving that knowledge is much more powerful than the logic of knowledge. Such a contradiction is inherent in every person. However, responsibility for the discrepancy between the customary and the proper ways is most inherent in the legal community, because law as a measure of justice in case of violation by the subjects of its provisions negatively affects the attitude not only towards them, but also towards the state as a political and legal institution of management. 
The purpose of the article is to consider the influence of mythological as well as religious and philosophical types of worldview on the formation of professional and civic qualities of a notary.

\section{Presentation of basic material}

A person as of his/her birth cannot but have a worldview, because the sense organs experience not only their own body, their own organism in all its integrity, but also realize it as the action of natural objects and social processes on the organs of perception, or analyzers. That is, a person as a natural biological being cannot but have an attraction to what is his continuation. Not only tools of labor, devices for enhancing the distinction of human perception organs are their inorganic continuation, but also the nature itself, since each person is a microcosm.

We give an opinion on this subject of L. Feuerbach as a leading representative of anthropological materialism. Speaking of sight as an organ of perception and at the same time an analyzer, he noted: "Man knows himself from the object: the consciousness of the object is the self-consciousness of man. Based on the object, we can learn a person and his essence. The object reveals the essence of man, his true objective "I". ... The gaze turned to the starry sky contemplates the selfless and harmless luminaries and sees in their radiance its own essence, its own origin. The nature of the eye is heavenly. Therefore, man rises above the earth only through sight, so the theory begins where the gaze turns to the sky. The first philosophers were astronomers. Heaven reminds man of his destiny, of the fact that he was created not only for activity but also for contemplation" (Feuerbach, 1955: 34).

It is easy to realize that the above excerpt, first, provides a definition of worldview as a person's self-consciousness; secondly, recognizes a man as a microcosm, which constantly attracts the macrocosm and whom from the very beginning of his enlightenment reaches out to his objective essence; thirdly, man feels his commensurability with the cosmos, so he begins his identification with the pronoun $\boldsymbol{I}$, not $\boldsymbol{W e}$; fourth, the usual view of the sky already awakens in a person a thirst for knowledge as self-knowledge.

In general, the mythological consciousness and, at the same time, the worldview projects all the diverse versatility of the mental components of a person onto the natural environment. It is as if nature itself, condensed into his body, is trying to regain its eternity and infinity. This is actually objective, because in this case the monistic unity of the human I with the Universe is achieved. It is as if his greatness is inherent in a person. It goes without saying that, having a potential charge, it cannot be actualized into a direct, reliable, both for himself and for others, powerful action. However, nothing prevents him from expressing such a scale of his consciousness, since it is in fact inherent in him. Therefore, this directly manifests itself in communication between people, not only in childhood, but in fact throughout life.

The way of thinking formed by mythology is based on an organic combination of images of fantasy with real animate phenomena and objects of nature. Fantasy is not a deception, but the objective reality of a person's consciousness in the pre-scientific level of his spiritual development. It is also his sincere belief that all natural processes as the interaction of material objects directly given to the organs of sensation / perception are controlled by humanlike beings. It is quite logical then that society should also have a certain managerial hierarchy, whereby power functions should belong to those whose spirit is capable of being inspired by the powerful forces of nature.

Since any form of consciousness has at least two levels - ordinary and theoretically ordered, it should be noted that the indisputable fact that the ordinary level of human being, first, has an existential dimension, and second, it already includes certain values that as if given to a 
person by nature, but which he perceives as a given, that does not require theoretical justification. That is, in fact, the direction / vector of development to the limiting and philosophical stages of being has already been determined.

The concept of a person as an individual reflects the psychophysiological worldview motivation of his life position, subordinate to the need to satisfy his basic needs on a daily basis. In this sense, they say that everyday life is depressing, prevents you from raising your eyes to the sky and see your greatness there too. On the other hand, human vision is never distracted from Heaven, therefore, on this level of his being, elements of the ultimate as personal arise, from which the path to the philosophical is not far.

Thus human existence occurs, which essence is that one needs to constantly be on the verge of life support. Therefore, you need to constantly strain your will to live. Constancy is immutability that bores, humiliates, does not develop; on the other hand, it is a manifestation of the law that a human may learn and use to his advantage. Invariable laws of nature, but the laws of society, which consists of people endowed with consciousness, subject to their will, subject, in turn, to cognitive thinking, able to go beyond the ordinary and mundane.

At the ordinary worldview level, each person has already an innate sense of dignity. This is important to take into account, since it is not a consequence of suggestion by thinkers who use the logic of reasoning, which, in turn, cannot be taken for granted. From birth, a person is inclined to listen to his own feelings and form a sense of dignity based thereon. Of course, from the standpoint of scientific knowledge, this is a manifestation of subjective idealism, subjectivism, solipsism and, ultimately, voluntarism. From the standpoint of everyday life, this is a manifestation of dignity as it is, because the perception of slightly different content of thought, not to mention the polar opposite, is perceived as its humiliation, denial. This is perhaps the main reason that progress in mutual understanding between people is extremely slow, so the history of mankind is constantly accompanied by wars. That is, it is also subject to existential measurement in the coordinates "to be" or "not to be".

It is extremely important to note the way to form a person's scientific and objective understanding of nature. Namely: when applying dialectics as a methodology of scientific knowledge, one should not be distracted from the dialectics that is spontaneously formed by the figurative and associative way of world perception and the worldview based thereon. At this point, future lawyers develop a sense of justice and injustice. It is fair to perceive the individual perception and explanation of the world as an existential truth. It is unfair to deny its genuineness. By the way, Aristotle actually deduced justice from injustice. Here we can find the origins of a notary lawyer: the truth is attested by the entire integrity of the child's organism, which reacts negatively to the denial of such a right.

When analyzing the religious type of worldview, it is important not to confuse it with the understanding that it acquired in its church version. A person, believing in God, is able to rise to a certain level of his being if he believes in his own godliness. At the level of a mythological worldview, he sees power in personified natural phenomena; at the level of religious and philosophical worldview and world outlook, he is pushed towards his own self-cognitive development, on the one hand, by the perception of his own similarity in the spiritual and creative sphere, which is facilitated by figurative and associative thinking as initial and primary; on the other hand, an example of the existence of godlike beings among people themselves. It is highly desirable that children perceive their parents, teachers, teachers of higher education in such a hypostasis, as adults in general, not by age, but by a rational-strong-willed way of life.

Please note that historically, philosophy and mythology as types of worldview were formed earlier than the religious worldview in a monotheistic essence. Therefore, we consider 
the gospel guidelines as a manifestation of a religious and philosophical type of worldview. Mind in the form of laws is inherent in both nature and human.

It is also necessary to define religion in terms of the meaning of the word itself, which really has magical power. The prefix re- means going back to the past; the root ligo- means connection. That is, the essence of religion as a life-giving spirit-creating word. That is, religion is the sanctity of a human connection with the past experience developed by the history of mankind, primarily with the history of cognitive activity in its impact on a human, taking into account this experience, which is not only able to correct the natural temperament, which often destroys for him, but also inspire truly creative achievements.

It is no coincidence that the good news from John the Theologian begins with the consecration of the word not only in the days of antiquity, but also in any periods of the history of mankind and the history of an individual. Thus, children, being born babies, enjoy them not only in childhood, but also as adults. J. Huizinga spoke beautifully about the role of speech as a human-creative power: "while creating language, the spirit constantly "flickers", jumps from the level of material to the level of thought, and is actually played with that wonderful nominative ability. The most daring of metaphors is hidden behind the name of each abstract concept, and if not a metaphor, it is a play on words. Thus, humanity, giving a verbal expression to life, creates with its natural world its second, poetic, world" (Huizinga, 1994: 11).

If we take an open-minded approach to the biblical texts, considering them as a philosophical figurative and associative, and not exclusively abstract and conceptual revelation, we have a clear confirmation of the decisive significance of the Logos / Word both in world- and human-creativity: "In the beginning was the Word, and the Word was with God, and the Word was God. The same was in the beginning with God. All things were made by him; and without him was not any thing made that was made. In him was life; and the life was the light of men. And the light shineth in darkness; and the darkness comprehended it not. There was a man sent from God, whose name was John. The same came for a witness, to bear witness of the Light, that all men through him might believe. He was not that Light, but was sent to bear witness of that Light. That was the true Light, which lighteth every man that cometh into the world. He was in the world, and the world was made by him, and the world knew him not. He came unto his own, and his own received him not. But as many as received him, to them gave he power to become the sons of God, even to them that believe on his name. Which were born, not of blood, nor of the will of the flesh, nor of the will of man, but of God."(Bible, 1994: 1255).

We specifically cited a rather lengthy reference, since it reveals the essence of the religious worldview from positions that take into account the peculiarities of the figurative and associative worldview. Let's try to highlight its main points that determine the direction of human development from the mythological to actually philosophical worldview and, thus, the world perception.

1. The "word" in Greek means logos, which also has the meaning of law, doctrine. Therefore, together with the word, as a means of communication between people, there is also a "communication" of all objects of nature in the process of their interaction and interchange of material structural elements, energy and information. In this sense, the world is ALL, because everything in it is subordinated to the One Law of universal interaction of everything with everything, while fully preserving its integrity.

2. The word of God in its ontological dimension is the very fact of indisputable existence of Being / Universe. The existence of mythological gods was confirmed ontologically - in the theater they were performed by real people who covered their faces with masks; in sculpture they were created by sculptors from dead materials. Meanwhile, an important component of 
the mythological consciousness, which is animatism as a belief in the eternal and immortal life. Therefore, there must be a human who is like God, since he is in everything and everything in him.

3. A human as a microcosm is similar to the macrocosm as it is related to God as the All through language, because it not only conveys evidence of events, but also contains the basic principles of the unity of Being and unity between people. This is the Light of knowledge and ways of their implementation, without which the darkness of misunderstanding and enmity shall reign.

4. This enlightened knowledge is inherent in philosophy, but it is not always confirmed by the way of their life, which could be employed by all people without exception. The Seneca was reproached for such inconsistency, to which he replied that he wrote about the good news precisely because it is so difficult to live, but the disclosure of moral principles of life already forces correction, because they are taken not as criticism of others, but as self-criticism. The generalized image of the philosopher was John, who was God sent, the wisdom that philosophy has developed over half a millennium of its existence.

5. John's mission, like that of any highly educated person, is to testify about the Light of Being, the Light of the All, and not to his own light, which is not always the case in its essence. Therefore, one should believe not in him, but in the Light.

6. The statement that such a bearer of Light was already among the people, but they did not perceive it, also reflects the everyday human inclination to believe that "it used to be better" than in their modern days. This removes the feeling of guilt, because human behavior is not determined solely by himself. Therefore, the collective philosopher of the past was revealed earlier, but now the contemporaries need to accept him as their own, because he came to his own.

7. A rather insignificant part of people at all times understand the guideline that it is pleasant to enjoy a moral, reasonable, and just life, as Epicurus commanded. Those who are capable of such a way of life are truly Light bearers, who in everyday speech are called "children of God", and quite often as sick people, or blissful "not of this world", because the other world is unknown to the bearers of such speech. They are the apostles in evangelical religious philosophy. As for religious philosophy, which took the form of Christianity, its creators were prominent philosophers, especially St. Augustine. We emphasize that religion is the sanctity of the connection of contemporaries with their ancestors, first of all with those who left immortal teachings after their biological death.

Thus, people who bring the Light of knowledge to the people are really born not as biological beings, but as spiritual Enlighteners of mankind. We are of the opinion that the category of people made up of notary lawyers, perhaps to the greatest extent among all other social groups of the population, is the bearers of the light of knowledge not just about laws, but about justice. After all, how does an average person assess the situation when he expresses his dissatisfaction with the application of the law to him? - He claims that it is not justice that is being done, but injustice. Therefore, he hopes for the righteous judgment of God not in this life, but after death. Since there is no life other than the biologically determined one, the task of those who assert legitimacy is to assert legitimacy of law as justice.

The rule of law the law will be taken as effective only if it will not be taken until the legislature elected by the majority as the right to own at branist, exclusiveness. This is always felt by notaries when they cannot certify a document that they consider fair, but the law does not. How do they feel that customers' claims to the legality of certain of their actions, which have legal significance and legal credibility, have no such grounds. This is where the talent for conveying to them their wrongdoing and the correctness of their arguments, built on the above evangelical principles, and not on purely rationalistic logical syllogisms, will be needed. One must also feel that the voice of the notary, the lawyer in general, is the voice and at the same 
time the logos of the man of God. It is not necessary to be afraid that the notary will believe in own divinity. After all, in such communication he remains equal with his interlocutors, because he is not perceived as a powerful man who does not have time to communicate with those who chose him, but as the master of reason and love for them.

A more or less in-depth analysis of what constitutes a religious type of worldview is due to the fact that, sadly, the consciousness of modern Ukrainian society, starting from school age, is much more strongly influenced by the church version of Christianity, priests and church hierarchs than the philosophical community. After all, it implements the ideas of Plato, Aristotle, whom Thomas Aquinas called the Teacher, Epicurus, Seneca, Augustine. It is not profitable for the clergy to tell the parish about this, leaving them in the dark ignorant of these obvious facts. Therefore, there is an additional desire to characterize the marginal level of human existence and how patristic as a philosophical version of the Christian religion has influenced the formation of human as a person, not just a psychophysiological individual.

A well-known researcher and connoisseur of medieval philosophy G.G. Mayorov among its most important principles included: theocentrism, creationism, providentialism, personalism and revelationism (Mayorov, 1979: 389-393). This is essential for the purposes of our study, because, paradoxically, it was during the period of more than a thousand years of domination of these fundamentals in the public consciousness that significant transformations occurred. First, everyday awareness has taken on a monotheistic direction; secondly, the spiritual elite of society was formed, represented by parish priests enjoyed trust and respect, which cannot be said about some representatives of the higher clergy; thirdly, universities developed, where the theological elite emerged, which, on the basis of discussions on the principle of sic et non, that is, yes or no, promoted freedom of thought, a deep development of its conceptual and categorical apparatus and the laws of logical thinking, as well as theology itself on the basis of philosophical teachings, primarily the teachings of Aristotle; fourthly, the philosophical and theological elite, being an intellectual stratum of theocratic form of statehood, while analyzing the texts of Holy Scripture, also had the status of godmen, whose thoughts had the status of the source of the Holy Spirit; fifth, the everyday mass consciousness was convinced with all obvious reliability that the driving force behind the development of society was precisely the highly spiritual elite. This was confirmed by the epochs of the Renaissance, Humanism, Reformation and Enlightenment, which relatively quickly, over several centuries, and not over a millennium, changed both the level and the quality of life.

Feuerbach clearly defined the true characteristics of religion: "The first, true, divine essence is not a property of a deity, but a godlike property. That is why what theology and philosophy recognized as God, absolute, essence, is not God. God is exactly what they did not consider to be God, that is, a property, quality, certainty, reality in general. A real atheist, that is, an atheist in the ordinary / customary sense, should be considered not the one who considers the divine subject as nothing, but the one who denies divine predicates such as love, wisdom, justice. ... The quality is divine not because it is inherent in God, but, on the contrary, it is inherent in God, because it is divine in itself, because God without it would be an imperfect being" (Feuerbach, 1955:51). Religion in its purely ecclesiastical version is, in his opinion, "the sleep of the human spirit" (Feuerbach, 1955:23). Hence the methodology of human awakening - active work on self-improvement. The imperfect will quickly notice the perfect and, with the appropriate involvement of the state, which servants, at the level of philosophical and legal education, will begin to imitate creative personalities, and not the traditions that were formed many millennia ago. Moreover, those traditions are not of their own people.

Studying the phenomenon of a notary in Ukrainian society, it is extremely important to train its intellectual philosophical and legal elite in this way. It is enough only to replace the 
concept of God with its true essential characteristics, and to understand religion itself as the sanctification of the law and the human right to justice. Then in the center of consciousness we will find: a) legal law; b) man as a creative being, c) which is guided by the law as a manifestation of the immutability and predictability of the development of both himself and society; d) he will acquire the status of an individual, whose outlook will constantly expand its horizons due to learning the revelations of the law in its humanistic dimension.

\section{Conclusions}

1. When training legal specialists, notaries, in particular, the principal attention should be paid to disclosing how the main structural components of the mythological and religious and philosophical worldview contribute to the formation of their stable value attitudes both regarding themselves and people whom they will serve.

2. It is extremely important to study the historical experience, because ignoring the civilizational humanistic achievements of the past shall counteract one of the basic laws of the progressive development of mankind. Namely: each next generation stands on the shoulders of its predecessors. Taking account of experience, and not voluntaristic attempts of the power, accelerates development.

The directions for further research should take into account the above conclusions. In addition, it is necessary to investigate the means of organic combination of innate natural human inclinations with those educational technologies that provide such a unity. This is how a significant increase in the subjectivity of a human in general, specialists in particular, is achieved.

\section{References}

1. Bible [Ukrainian Bible Society]. (1994). Kyiv: [in Ukrainian]

2. Huizinga J. Homo ludens. (1994). Kyiv: Basics. [in Ukrainian]

3. G.G. Mayorov (1989). [ Formation of medieval philosophy ] / G.G. Mayorov. (1989). Moscow. Mysl.

4. Feuerbach L. (1955). The Essence of Christianity. L. Feuerbach. Selected Philosophical Works. In 2 volumes. Moscow. Politizdat. 